\title{
Price Markups for Small and Large Firms Over the Business Cycle
}

\author{
Sungki Hong, Economist
}

U nderstanding the dynamics of firm market power is an important issue in macroeconomics. One empirical measure of market power is the price markup, a ratio of price over the marginal cost of production. If a firm's price is relatively high compared with its marginal cost, it implies that the firm exerts high market power. Numerous studies (e.g., Chari, Kehoe, and McGrattan, 2007; and Bils, Klenow, and Malin, 2016) have found that variations in markup account for much of the fluctuations in aggregate output and employment over business cycles. Also, markup cyclicality has important implications for inflation dynamics. As the cost of goods production rises and falls over time, the variation in markups could amplify or dampen the movements of final product price. Blanchard and Gali (2007) stress that understanding this interaction "should be high on macroeconomists' research agendas." Finally, a recent study by Autor et al. (2017) finds that the rise in market power of superstar firms contributes much to the rise in the corporate profit share of a firm's revenue and, correspondingly, the secular decline in the labor share of revenue over the past 30 years.

Small firms exhibit more countercyclical markups than large firms over the business cycle.

In this essay, I measure markup behaviors at the firm level (as opposed to the aggregate level usually measured in the literature). I use firm-level data in manufacturing sectors of France from the Bureau van Dijk (BvD) Amadeus dataset. I focus on the manufacturing sector because it suits the estimation of production functions. The industries cover a wide range of manufacturing, from food products and beverages to motor vehicles, trailers, and semitrailers. The dataset contains both financial balance sheet and production data. However, the dataset provides neither the prices nor the marginal costs necessary for directly measuring markup. Instead, I follow insights from Hall (1986) and De Loecker and Warzynski (2012), relying on the firm's optimality condition of cost minimization with respect to a static input. Therefore, I use material inputs for markup estimations because materials do not suffer much from adjustment costs or other dynamic considerations. Previous studies measure the markup with labor inputs, but it is well known that the measurement of the true costs of labor inputs suffers from several frictions, including hiring and firing costs and overhead costs.

With the assumptions stated above, the firm-level markup is proportional to the inverse of the material cost share of revenue:

$$
\mu_{i t} \propto \frac{\text { Revenue }_{i t}}{\text { Material Cost }_{i t}} .
$$

I take business cycle measures from Eurostat and FRED ${ }^{\circledR}$. I use real GDP as the main measure of the business cycle and detrend quadratically.

To empirically test markup cyclicality, I bring the following specification to the data:

$$
\log \mu_{i t}=\alpha_{i}+\phi_{0} \log Y_{t}+\phi_{1} \log Y_{i t} \times \Omega_{i t}^{\prime}+\chi_{i t}^{\prime} \beta+\epsilon_{i t},
$$

where $\mu_{i t}$ is the firm-level markup, $\alpha_{i}$ is the firm's fixed effect, $Y_{t}$ is real GDP, $\Omega_{i t}$ is a vector of the firm's characteristic variables, and $\chi_{i t}$ is a vector of control variables; $\phi_{0}$ captures the average markup cyclicality for all firms; and $\phi_{1}$ captures the heterogeneity in markup cyclicality across firms.

The table reports the results for this specification. Column (1) shows that the markup is countercyclical and statistically significant for all firms. The elasticity of the markup with respect to aggregate output is -1.1 . This means that a 1 percent increase in output from its nonlinear trend causes the markup to decline by 1.1 percent.

Moreover, with micro-level data, I find that there is substantial heterogeneity in markup cyclicality. One interesting and important aspect is whether markup cyclicality depends on firm size. Markups of small and large firms have the potential to move differently for several reasons, including firm-brand reputation and pricing adjustment frictions. 


\begin{tabular}{|c|c|c|c|c|c|}
\hline \multirow{3}{*}{$\begin{array}{l}\text { Dependent variables } \\
\qquad \log \mu_{i t}\end{array}$} & \multicolumn{3}{|c|}{ Heterogeneity in Markup Cyclicality } & \multirow[b]{2}{*}{ (4) } & \multirow{3}{*}{$\begin{array}{l}\text { (5) } \\
\text { All }\end{array}$} \\
\hline & (1) & (2) & (3) & & \\
\hline & All & Large & Small & All & \\
\hline $\log Y_{t}$ & $\begin{array}{l}-1.13^{* * *} \\
(0.17)\end{array}$ & $\begin{array}{l}-0.76^{* * *} \\
(0.21)\end{array}$ & $\begin{array}{l}-1.21^{* * *} \\
(0.16)\end{array}$ & $\begin{array}{l}-1.21^{* * *} \\
(0.16)\end{array}$ & $\begin{array}{l}-1.22^{* * *} \\
(0.18)\end{array}$ \\
\hline $\log Y_{t} \times \operatorname{Large}_{i}$ & & & & $\begin{array}{l}0.45^{* * *} \\
(0.12)\end{array}$ & \\
\hline $\log Y_{t} \times M k t$ Share $_{i t}$ & & & & & $\begin{array}{l}6.13^{* * *} \\
(1.79)\end{array}$ \\
\hline Number of observations & 96,507 & 16,048 & 80,459 & 96,507 & 96,507 \\
\hline Adjusted $R^{2}$ & 0.89 & 0.87 & 0.89 & 0.89 & 0.89 \\
\hline
\end{tabular}

SOURCE: BvD Amadeus, FRED ${ }^{\circledR}$, and author's calculations.

NOTE: Standard errors are in parentheses. ${ }^{*} p<0.10,{ }^{* *} p<0.05,{ }^{* * *} p<0.01$.

\section{A. Mean Markups of All Firms}

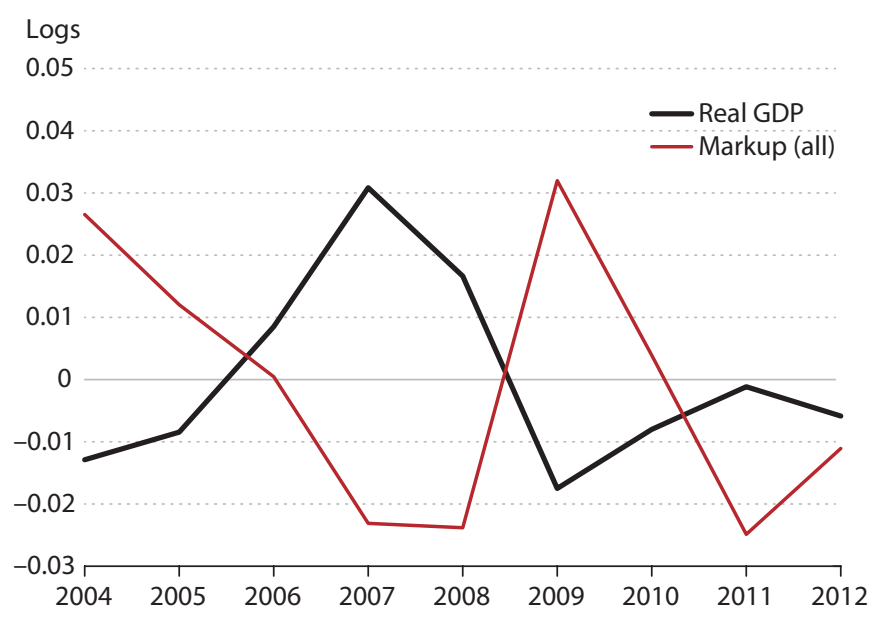

\section{B. Mean Markups of Small and Large Firms}

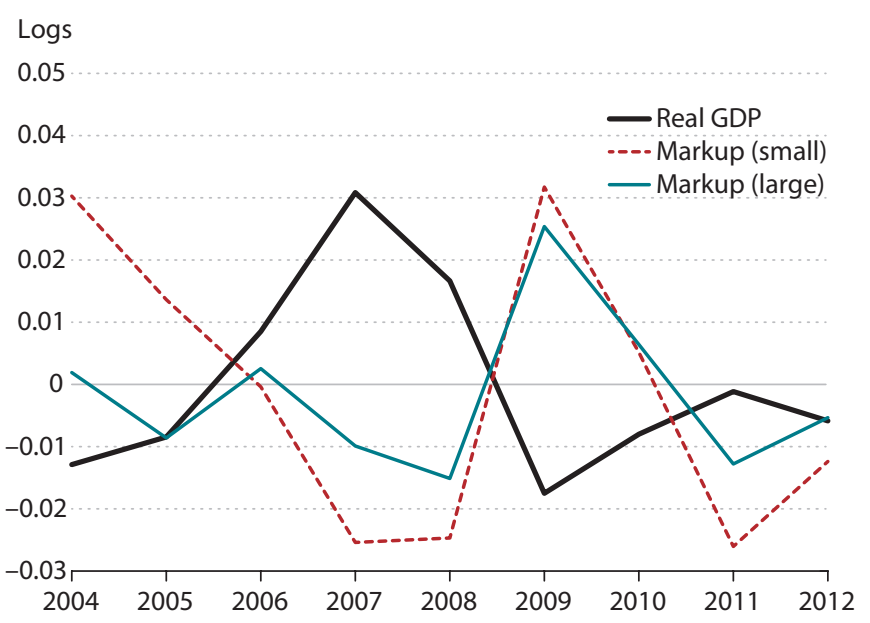

NOTE: Small firms account for 83 percent of the mean markups of all firms, and large firms account for 17 percent. SOURCE: BVD Amadeus, FRED ${ }^{\oplus}$, and author's calculations.

To explore the heterogeneity, I group firms by size: large and small. I define a large firm as one with more than 1 percent market share within its four-digit industry. Columns (2) and (3) report the results for subsamples of large and small firms, respectively. I find that the large firms' markup elasticity is small, equal to -0.76 , and that the small firms' markup elasticity is larger, at -1.21 . This implies that small firms' markups fluctuate 45 percent more than large firms' along the business cycle. Recently, Bils, Klenow, and Malin (2016) used intermediate inputs to estimate markup cyclicality at the industry level and found that elasticity with respect to real GDP is equal to -0.9 . My finding with the large firms is largely comparable to this number because large firms drive most of the industry-level markup, by definition. Another way to identify differential effects between small and large firms is by pooling all firms and interacting aggregate output $Y_{t}$ with a dummy variable, Large $_{i}$, as in column (4). The results show that the difference is significant. Alternatively, instead of using a dummy variable, I interact aggregate output with the market share of revenue, MktShare $_{i t}=\frac{\text { Revenue }_{i t}}{\sum_{i} \text { Revenue }_{i t}}$. The results in column (5) indicate the same findings.

Finally, I plot the time series of real GDP and the average firm-level markup over the sample period. In panel A of the figure, I plot the mean markups after controlling for fixed effects for all firms. Again, the figure shows that firms' markups are countercyclical. Notice that the markups show strong countercyclicality from the beginning to the end of the sample period. In panel B, I plot the mean 
markups for firms with less than 1 percent market share (small) and for firms with more than 1 percent market share (large), respectively. We clearly see that smaller firms are more sensitive to the business cycle than large firms.

With the micro-level data, I confirm the old finding that markups are countercyclical but also find that markups of small firms are relatively more cyclical. To better understand the welfare implication of markup variations, we need a theory or model in which firm-level price over marginal cost choices are consistent with the data. It also has important implications for policymakers at the central bank in targeting inflation rates over the business cycle.

\section{References}

Autor, D.; Dorn, D.; Katz, L. F.; Patterson, C. and Van Reenen, J. “The Fall of the Labor Share and the Rise of Superstar Firms." National Bureau of Economic Research, 2017; https://doi.org/10.3386/w23396.

Bils, M.; Klenow, P. J. and Malin, B. A. "Resurrecting the Role of the Product Market Wedge in Recessions." Technical Report, National Bureau of Economic Research, 2016.

Blanchard, O. and Gali, J. "Real Wage Rigidities and the New Keynesian Model." Journal of Money, Credit and Banking, 2007, 39(1), pp. 35-65; https://doi.org/10.1111/j.1538-4616.2007.00015.x.

Chari, V. V.; Kehoe, P. J. and McGrattan, E. R. "Business Cycle Accounting." Econometrica, 2007, 75(3), pp. 781-836;

https://doi.org/10.1111/j.1468-0262.2007.00768.x.

De Loecker, J. and Warzynski, F. "Markups and Firm-Level Export Status." American Economic Review, 2012, 102(6), pp. 2437-471; https://doi.org/10.1257/aer.102.6.2437.

Hall, R.E. "Market Structure and Macroeconomic Fluctuations." Brookings Papers on Economic Activity, 1986, 2, pp. 285-322; https://doi.org/10.2307/2534476. 